\title{
Synthesis of New N-Substituted Phenoxazine Derivatives
}

\section{Israa Taha Ibraheem}

Department of Chemistry, College of Science, University of Baghdad, Baghdad, Iraq.
Received 6/10/2015

Accepted 20/12/2015

(ब) $(9 \Theta$

EY NO ND This work is licensed under a Creative Commons Attribution-NonCommercialNoDerivatives 4.0 International Licens

\begin{abstract}
This work comprises the synthesis of new phenoxazine derivatives containing $\mathrm{N}$-substituted phenoxazine starting from phenoxazine (1). Synthesis of ethyl acetate phenoxazine (2) through the reaction of phenoxazine with ethylchloroacetate, which reacted with hydrazine hydrate to give 10-aceto hydrazide phenoxazine (3), then reacted with formic acid to give 10-[ $\mathrm{N}$-formyl acetohydrazide] phenoxazine (4). Reaction of compound (4) with phosphorous pentaoxide or phosphorus pentasulphide to gave 10-[N-methylene-1,3,4-oxadiazole] phenoxazine (5) and 10-[N-methylene1,3,4-thiadiazole] phenoxazine (6).
\end{abstract}

Key words: phenoxazine, ethyl acetate phenoxazine, 10-aceto hydrazide phenoxazine.

\section{Introduction:}

Heterocyclic compounds are cyclic compounds in which the ring atoms are of carbon and some other elements containing nitrogen, oxygen and sulfur, the most common other atoms such as boron, phosphorus or silicon compound also be members of heterocyclic ring. Some nonaromatic heterocyclic and some aromatic heterocyclic [1-4]. In 1887, the phenoxazine was made by Bernth [5] and though known for many years has not had a systematic study made of its chemistry. And till the last decade, little was known about the metabolism of phenoxazine in biological systems [6]. The heterocyclic oxygen atom of the phenoxazine nucleus places certain restriction on the aromaticity of this ring system, which appears to be somewhat less aromatic than the phenothiazine system for instance. The aromatic model shows that the phenoxazine nucleus is slightly folded along its short axis i.e., the axis passing through the two central hetero atoms. The dipole moment of phenoxazine which was found to be 1.93 D (benzene) [7] is also consistent with the non planarity of molecule. Phenoxazine nucleus is highly nonplaner, i.e., folded along the axis passing through the two heteroatoms $[8,9]$.

\section{Materials and Methods:}

UV spectra were recorded on UVvisible spectrophotometer (SHIMADZU) UV-160 A. FT-IR spectra were recorded on (SHIMADZU) 
FT-IR 8400 S spectrophotometer; solid samples were run as smears. Melting points were recorded using a (Gallen kamp) melting point apparatus with sample contained in open capillary glass tube in an electrically heated metal block apparatus. ${ }^{1} \mathrm{H}-\mathrm{NMR}$ spectra were recorded on Ultra Sheild $300 \mathrm{MH}_{\mathrm{z}}$ with tetramethyl silane as internal standard and DMSO and methanol as solvents. Thin Layer chromatography (T.L.C.) were performed on pre-coated sheet with $0.25 \mathrm{~mm}$ Layer of silica-gel F 254. Spots were detected with iodine vapour.

\section{General Procedure for Synthesis of} Phenoxazine and its Derivatives:

Phenoxazine (1):

A mixture of $(2 \mathrm{~g}) \mathrm{ZnCl}_{2},(109 \mathrm{~g}$, $1 \mathrm{~mol})$ of o-aminophenol and $5 \mathrm{ml}$ conc. $\mathrm{H}_{3} \mathrm{PO}_{4}$ was heated in a sand bath at 270$275{ }^{\circ} \mathrm{C}$ for 4 hours. The reaction mixture was cooled and extracted with cyclohexane in soxhlet extraction apparatus, the solvent was removed and the formed colorless needles crystallized from ethanol m.p. $152-154{ }^{\circ} \mathrm{C}$, yield (54g,50\%) IR: $3405 \mathrm{~cm}^{-1}(\mathrm{~N}-\mathrm{H}) \mathrm{str}$.

\section{Ethyl Acetate Phenoxazine (2):}

A mixture of phenoxazine (1), (5g, $0.027 \mathrm{~mol})$, ethylchloroacetate $(3.5 \mathrm{ml}$, $0.027 \mathrm{~mol})$ in dry acetone $(5 \mathrm{ml})$ and anhydrous $\mathrm{K}_{2} \mathrm{CO}_{3}(0.5 \mathrm{~g})$ was refluxed for 24 hours, then cooled, filtered and solvent removed under reduced pressure. The resulting solid was monitored by (T.L.C) using $\left(\mathrm{CCl}_{4}: \mathrm{EtOH}\right) \quad(3: 1)$ as eluent and recrystallized from ethanol, m.p (148 $\left.{ }^{\circ} \mathrm{C}\right),(1.3 \mathrm{~g}$, yield $34 \%)$.

\section{0-aceto Hydrazide Phenoxazine} (3):

A solutione of compounde (2) (2.5g, $0.009 \mathrm{~mol})$ in ethanol $(50 \mathrm{ml})$, hydrazine hydrate $(0.5 \mathrm{ml}, 0.009 \mathrm{~mol})$ was added and the reaction mixture was refluxed on a water bath for 2-3 hours. Reaction and purity of the final product was checked by (T.L.C) using $\left(\mathrm{CCl}_{4}: \mathrm{EtOH}\right)$ (3:1) as eluent and recrystallized from ethanol, m.p $\left(140{ }^{\circ} \mathrm{C}\right),(1 \mathrm{~g}$, yield $81 \%)$.

\section{0-[N-formylacetohydrazide] Phenoxazine (4):}

A solution of compound (3) $(2.87 \mathrm{~g}, 0.01 \mathrm{~mol})$ in formic acid (20 ml) was refluxed for 20 minutes. The solvent was evaporated and the residue was recrystallized from methanol. The product was checked by (T.L.C) using $\left(\mathrm{CCl}_{4}: \mathrm{EtOH}\right)(3: 1)$ as eluent, m.p $\left(124^{0} \mathrm{C}\right),(0.4 \mathrm{~g}, 36 \%)$.

\section{0-[N-methylene-1,3,4- Oxadiazole]Phenoxazine (5):}

A solution of compound (4) (1 g, $0.001 \mathrm{~mol})$ in o-xylene $(50 \mathrm{ml})$, phosphorous pentaoxide $(0.5 \mathrm{~g})$ was added. The mixture refluxed for 1 hour. The solvent was evaporated, then water (10 ml) was added, and the mixture was extracted with chloroform. The solvent was evaporated and the residue was checked by (T.L.C) using $\left(\mathrm{CCl}_{4}: \mathrm{EtOH}\right)$ $(3: 1)$ as eluent and recrystallized from benzene or ethyl acetate, m.p. $\left(116{ }^{0} \mathrm{C}\right)$, yield $(0.1 \mathrm{~g}, 71 \%)$.

\section{0-[N-methylene-1,3,4- thiadiazole]Phenoxazine (6):}

Compound (6) was prepared by the same method described for the preparation of compound (5), using phosphorus pentasulphide, m.p. $\left(142^{0} \mathrm{C}\right)$, yield $(0.1 \mathrm{~g}, 50 \%)$.

\section{Results and Discussion:}

Phenoxazine was prepared by the reaction of o-aminophenol with zinc chloride in presence of phosphoric acid as showed in Scheme (1). Phenoxazine (1) showed strong stretching band at $3342 \mathrm{~cm}^{-1}(\mathrm{~N}-\mathrm{H})$, strong stretching bands at $1570 \mathrm{~cm}^{-1}$ and $1596 \mathrm{~cm}^{-1}$ assigned to phenoxazine ring. The ${ }^{1} \mathrm{H}$ NMR spectrum [10] showed signal at $\delta$ 
(6.7-7) $\mathrm{ppm}$ signals to aromatic protons and signal at $\delta(8.2)$ ppm a ssignal to $(\mathrm{N}-$ $\mathrm{H})$ shown in Figure (1). The phenoxazine (1) was then converted to ethyl acetate phenoxazine (2) using ethylchloroacetate. IR spectrum of compound (2) showed the disappearance of $(\mathrm{N}-\mathrm{H})$ band at $3342 \mathrm{~cm}^{-1}$ and showed a stretching band at $1629 \mathrm{~cm}^{-1}(\mathrm{C}=\mathrm{O})$. The IR spectrum also showed a band at $3090 \mathrm{~cm}^{-1}(\mathrm{C}-\mathrm{H})$ aromatic, at $2977 \mathrm{~cm}^{-1}$ (C-H) aliphatic and $1585 \mathrm{~cm}^{-1}(\mathrm{C}=\mathrm{C})$. Compound (2) reacted with hydrazine hydrate to gave compound (3). The IR spectra of compounds (3) showed strong stretching band at $3397 \mathrm{~cm}^{-1}(\mathrm{~N}-\mathrm{H})$, at $1640 \mathrm{~cm}^{-1}(\mathrm{C}=\mathrm{O})$ str. and $1595 \mathrm{~cm}^{-1}$ $(\mathrm{C}=\mathrm{C})$ as showed in Table (1). Compound (3) reacted with formic acid to gave compounds (4). IR spectrum of compounds (4) showed absorption band at $3406 \mathrm{~cm}^{-1}(\mathrm{~N}-\mathrm{H}), 1695 \mathrm{~cm}^{-1}(\mathrm{C}=\mathrm{O})$ str, $1583 \mathrm{~cm}^{-1}(\mathrm{C}=\mathrm{C})$ str. and ${ }^{1} \mathrm{HNMR}$ spectra Figure (2) for compound (4) showed signal at ( $\begin{array}{cc}6-6.5) & \mathrm{ppm}\end{array}$ belong to $(\mathrm{N}-\mathrm{H})$ proton for amide, singal at $\sigma(2-2.5) \mathrm{ppm}$ belong to $\left(\mathrm{CH}_{2}\right)$, singal at $\sigma(8.9-9.1) \mathrm{ppm}$ belong to $(\mathrm{CH})$ and signals at $\boldsymbol{\nabla}$ (7.38) ppm belong to aromatic protons [11]. Compound (4) reacted with phosphorous pentaoxide or phosphorus pentasulphide to gave compound (5) and (6). IR spectrum of compounds (5) showed absorption strong bands at 1620 $\mathrm{cm}^{-1}(\mathrm{C}=\mathrm{N}) \mathrm{str}, 1585 \mathrm{~cm}^{-1}(\mathrm{C}=\mathrm{C})$ str., IR spectrum of compounds (6) showed absorption strong bands at $1627 \mathrm{~cm}^{-1}$ $(\mathrm{C}=\mathrm{N}) \mathrm{str}, 1585 \mathrm{~cm}^{-1}(\mathrm{C}=\mathrm{C}) \mathrm{str}$.

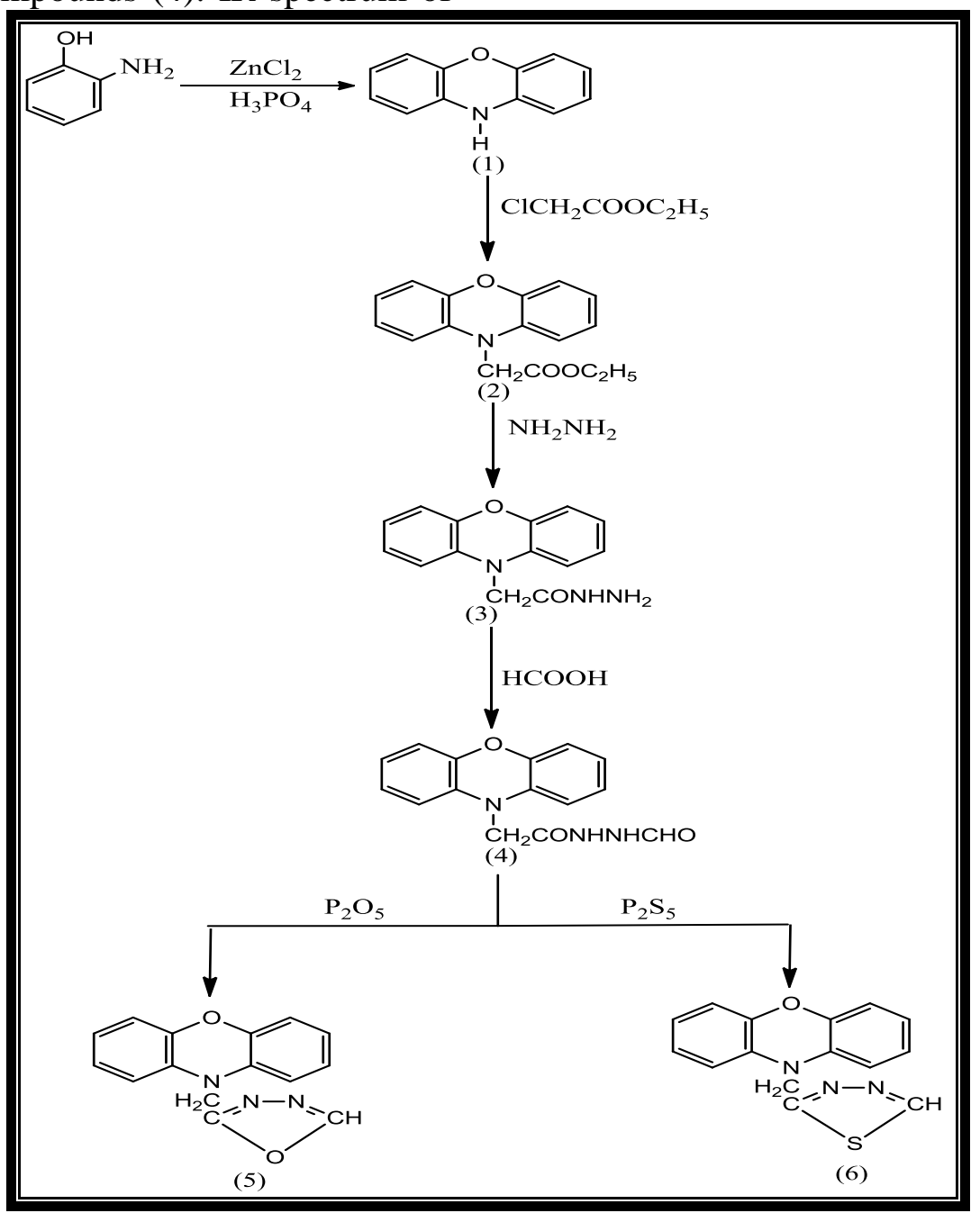

Scheme (1) Synthetic path way for preparation of new Hetrocyclic compounds. 
The $2^{\text {nd }}$ National Conference of Chemistry

Table (1): Infrared spectral data of compounds (2-6)

\begin{tabular}{|c|c|c|c|c|c|c|c|}
\hline $\begin{array}{c}\text { Compd. } \\
\text { No. }\end{array}$ & Structure & $\begin{array}{c}\text { v C-H } \\
\text { Aromatic }\end{array}$ & $\begin{array}{c}\text { v C-H } \\
\text { Aliphatic }\end{array}$ & $\begin{array}{c}\text { v } \mathbf{C}=\mathbf{C} \\
\mathbf{c m}^{-1}\end{array}$ & $\begin{array}{c}\text { v } \mathrm{C}=\mathrm{O} \\
\mathbf{c m}^{-1}\end{array}$ & $\begin{array}{c}v \mathrm{C}=\mathrm{N} \\
\mathrm{cm}^{-1}\end{array}$ & $\begin{array}{c}\text { Other } \\
\text { bands } \\
\text { cm }^{-1}\end{array}$ \\
\hline 2 & $\mathrm{CH}_{2} \mathrm{CC}$ & $3090 \mathrm{w}$ & 2977 w & $1585 \mathrm{~s}$ & $1629 \mathrm{~s}$ & - & - \\
\hline 3 & $\mathrm{CH}_{2} \mathrm{C}$ & 3085 m & 2923 w & $1595 \mathrm{~s}$ & $1640 \mathrm{~s}$ & - & $\begin{array}{l}\text { N-H } \\
3397\end{array}$ \\
\hline 4 & $\mathrm{CH}_{2} \mathrm{CONH}$ & 3080 m & $2991 \mathrm{w}$ & $1583 \mathrm{~s}$ & $1695 \mathrm{~s}$ & - & $\begin{array}{l}\text { N-H } \\
3406\end{array}$ \\
\hline 5 & & 3041 m & $2885 \mathrm{~m}$ & $1585 \mathrm{~s}$ & - & $1620 \mathrm{~s}$ & $\begin{array}{c}\text { C-O-C } \\
1147\end{array}$ \\
\hline 6 & $\mathrm{CH}_{2}$ & $3030 \mathrm{~m}$ & $2923 \mathrm{~m}$ & $1585 \mathrm{~s}$ & - & $1627 \mathrm{~s}$ & C-S 712 \\
\hline
\end{tabular}

Table (2): physical properties of compounds (2-6)

\begin{tabular}{|c|c|c|c|c|c|}
\hline Comp. No. & Structure & M.P. ${ }^{\circ} \mathrm{C}$ & $\%$ Yield & Color of crystal & Solvent \\
\hline 2 & $\mathrm{CH}_{2} \mathrm{CC}$ & 148 & 34 & Yellowsh green & Ethanol \\
\hline 3 & $\mathrm{CH}_{2} \mathrm{C}$ & 140 & 81 & Off-White & Ethanol \\
\hline 4 & $\mathrm{CH}_{2} \mathrm{COI}$ & 124 & 36 & Light Brown & methanol \\
\hline 5 & & 116 & 71 & Black & Ethylacetate \\
\hline 6 & $\mathrm{CH}_{2}$ & 142 & 50 & Black & Benzene \\
\hline
\end{tabular}


Table (3): ${ }^{1} \mathrm{H}$-NMR spectral data for compounds $(1,4)$

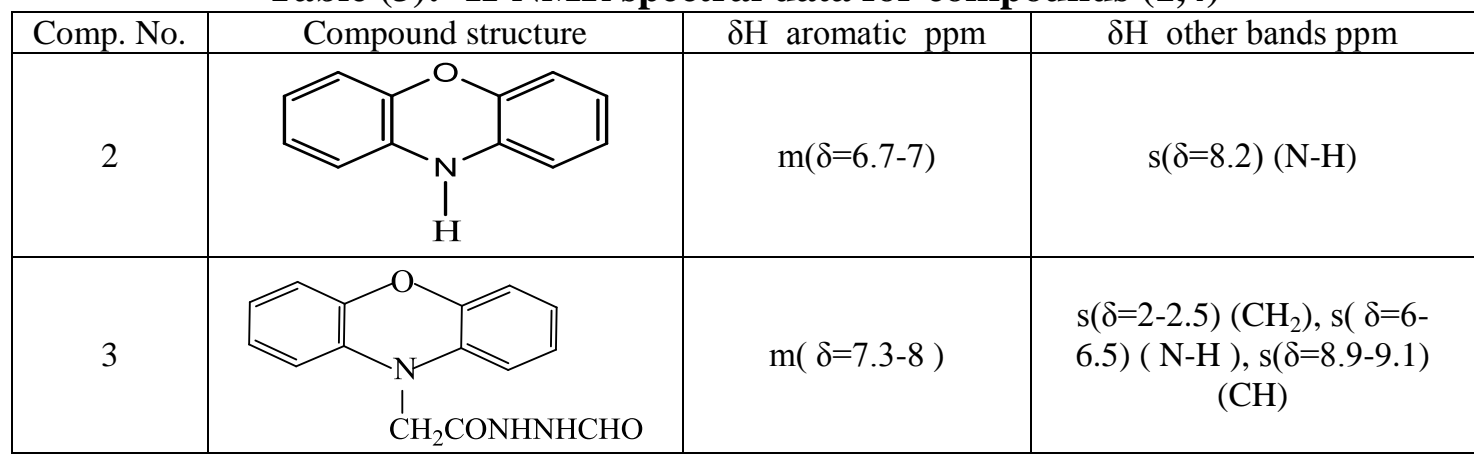

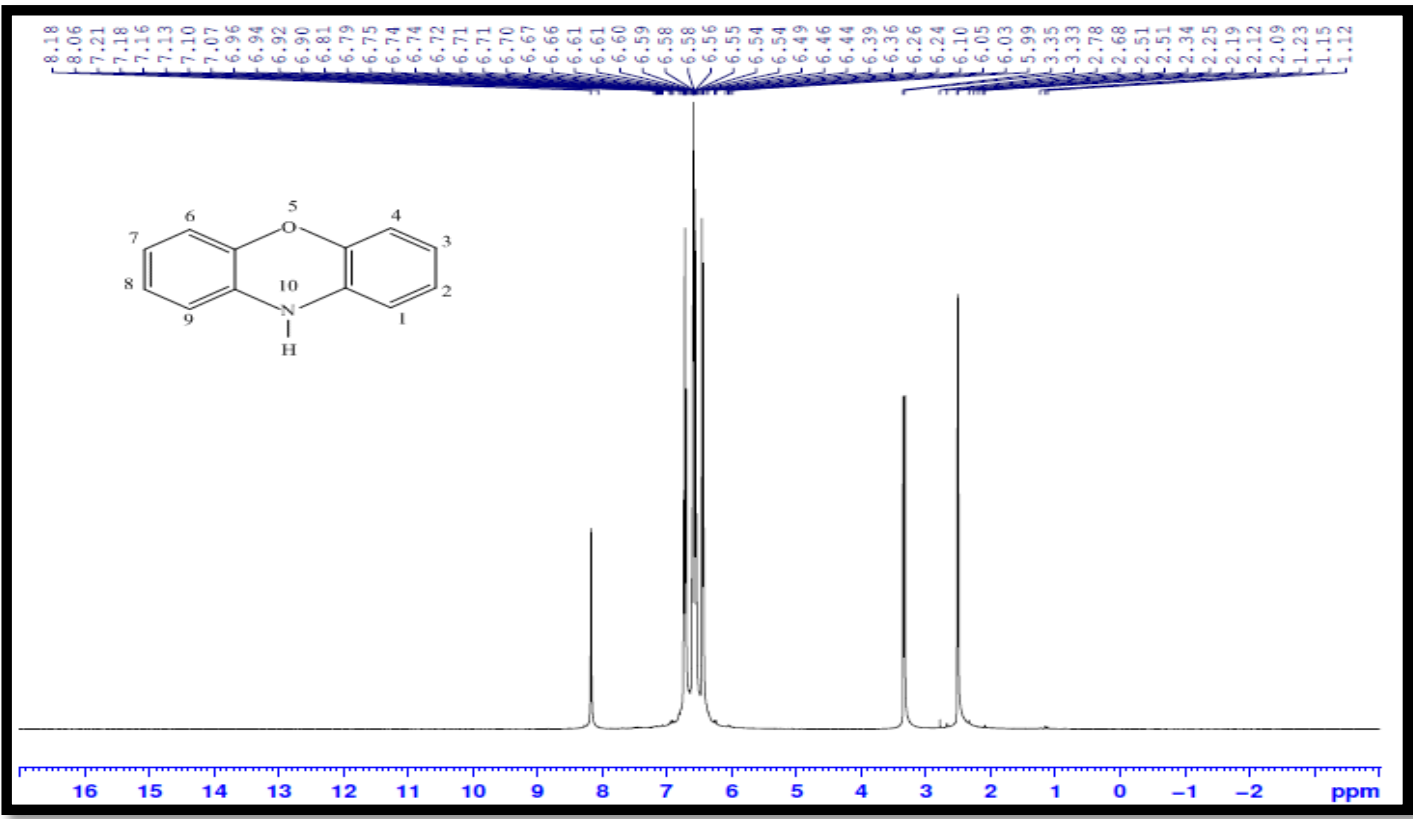

Fig. (1): ${ }^{1} \mathrm{H}-\mathrm{NMR}$ spectrum of compound (1)

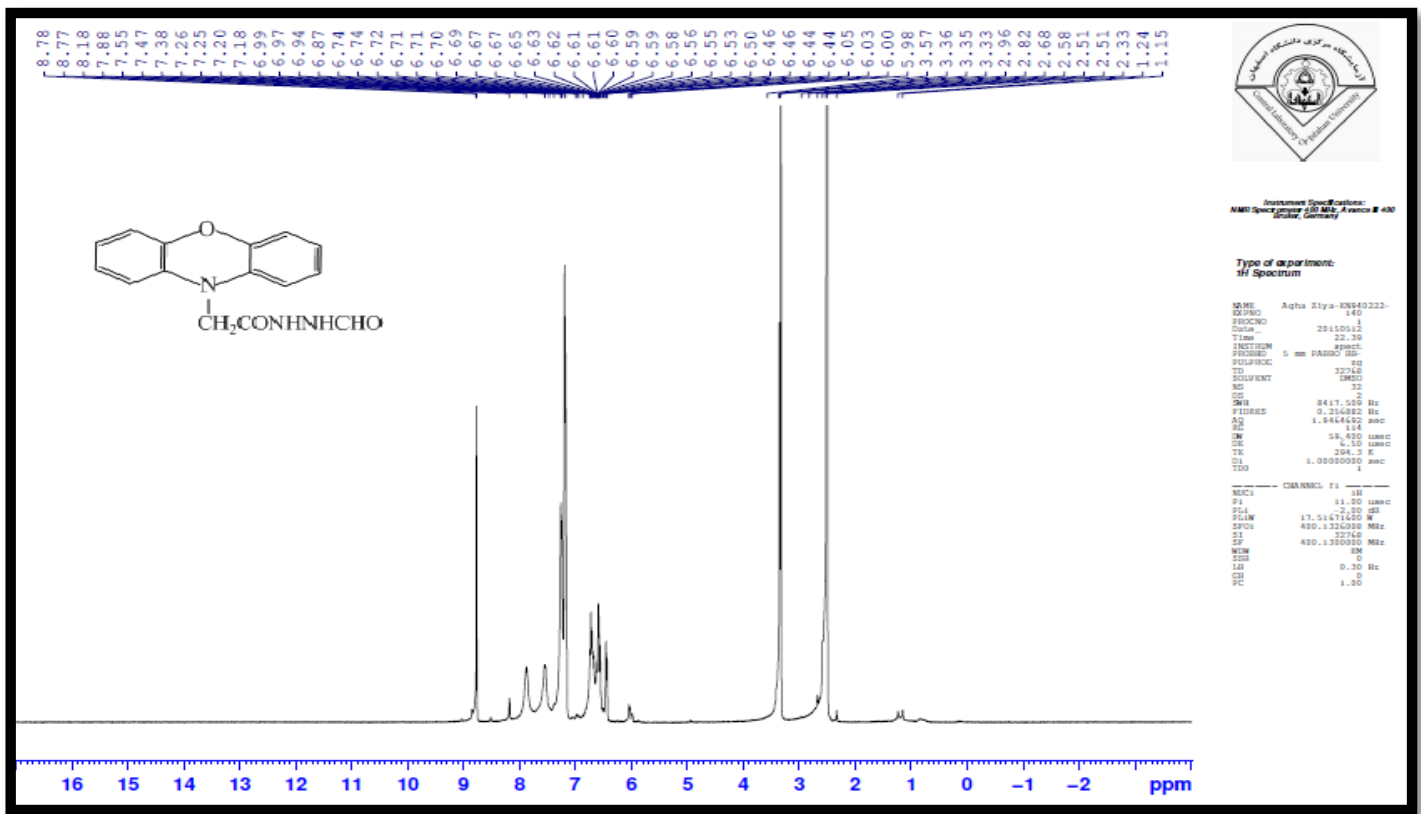

Fig. (2): ${ }^{1} \mathrm{H}-\mathrm{NMR}$ spectrum for compound [4] 


\section{Conclusion:}

Phenoxazine derivatives are an important type of nitrogen and oxygen containing heterocyclic compounds which have attracted considersion of medicinal chemist due to antimicrobial activites for this purpose new phenoxazine derivatives were synthesized. More than 5 derivatives were prepared and characterized by spectroscopic methods namely FT-IR and some of them with ${ }^{1} \mathrm{H}-\mathrm{NMR}$.

\section{References:}

[1] Bahl, A. and Bahl, B. S. 2000. Organic Chemistry. 4 ed., WileyInterscience, New York, p:849.

[2] Raj, K.B. 2007.Organic Chemistry. 5 ed., Wiley-Interscience, New York, p:836

[3] Bahl. A. and Bahl. B. S. 2008. Advanced Organic Chemistry., 21 ed., Wiley-Interscience, Blackwell, $\mathrm{p}: 1201$.

[4] Jone, A. J. and Mills, K. 2006. Heterocyclic Chemistry at a Glance. 2 ed., Wiley-Interscience, United Ringdom, p:554.

[5] Bernthsen, A. 1887. Synthesis of phenoxazine, J. Org. Chem. 20(1):939-942.
[6] Crossley, M. L., Hofmann, C. M. and Dreisbach, P. F. 1952. Chemotherapeutic Dyes.1.5Aralkylamino-9-alkylamino benzo[a] phenoxazines ${ }^{1}$. J. Am. Chem. Soc., 74(12):580-584.

[7] Freedlander. 1944. In vivo staining of fat in tumor bearing mice by benzo (a) phenoxazine dyes. Proc. Soc. Exp. Biol., New York, 57(3)p: 106.

[8] Yang, L. and Feng, J. K. 2006. Theoretical investigations on the modulation of the polymer electronic and optical properties dy introduction of phenoxazine. Am. Ren and $\mathrm{Cc}$ Sun, Polymer, 47(9):3229.

[9] Keleş, H. and Dehri, I.2005. Applied Surface Science. 4 ed. Strasbourg, France, p:630.

[10] Al-Barzinji, D. J. 2006. Synthesis of new 10-substituted phenoxazine derivatives, M. Sc. Thesis, College of Science, University of Baghdad, p:130.

[11] Gban, M. A. 2011. Synthesis of new Heterocyclic compounds derived 5,10-dihydrophenophosphazine,

M.Sc. Thesis, College of Science, University of Baghdad, p:160.

\footnotetext{
تحضير مشتقات جديدة للاينوكسازين معوضة على ذرة التتروجين

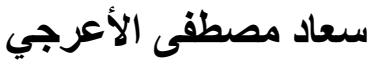$$
\text { إسراء طه إبراهيم }
$$$$
\text { قسم الكيمباء، كلية العلوم، جامعة بغداد، بغداد، العر اق. }
$$

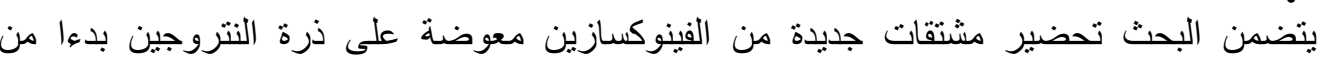

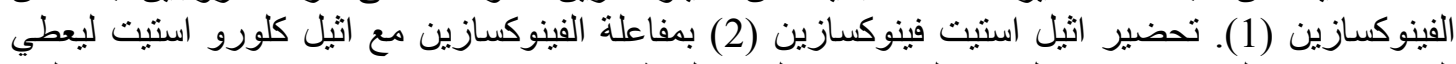

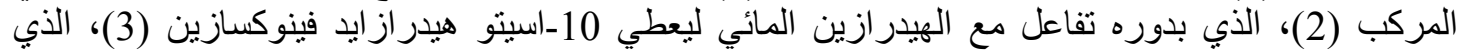

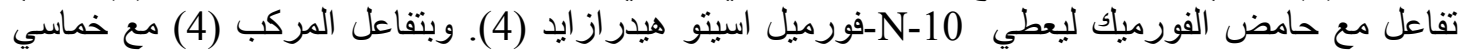

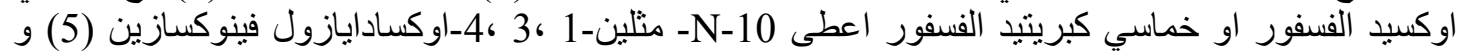

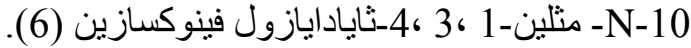$$
\text { الكلمات المفتاحية: فينوكسازين، أثيل استيت فينوكسازين، 10_أسيتو هيدرازايد فينوكسازين. }
$$ 